\title{
Hvordan påvirker veilederutdanningene utøvelse av veilederrollen? En analyse av forventninger uttrykt i styringsdokumenter, forskning og faglitteratur
}

\author{
Eli Lejonberg ${ }^{1 *}$ \\ ${ }^{1}$ Universitetet i Oslo
}

\begin{abstract}
Sammendrag
Fokuset i denne artikkelen er på veilederutdanningene som skolerer veiledere for lærerstudenter og nyutdannede lærere. Formålet er å belyse hvordan forventninger uttrykt i styringsdokumenter, forsknings- og faglitteratur bidrar til å forme veilederrollen. I styringsdokumentene som analyseres, fremmes ulike forventninger, eksempelvis er det i retningslinjer for veilederutdanningene vektlagt forventninger om at veileder skal være lyttende og innta rollen som kritisk venn tydelig, men det åpnes også for en mer mangefasettert veilederrolle. De unders $\varnothing$ kte stortingsmeldingene karakteriseres av formuleringer som åpner for ulike veilederroller, mens undersøkte utredninger bestilt av Kunnskapsdepartementet vektlegger rollen som lytter og kritisk venn. Analysene viser også at forventninger om at en veileder skal være lyttende og innta rollen som kritisk venn står sterkt $i$ faglitteraturen som brukes i veilederutdanningene og i forskning. Det er imidlertid også forskning som nyanserer bildet og hvor eksempelvis en guidende rolle trekkes frem som hensiktsmessig. I lys av funnene diskuteres implikasjoner for veiledning i praksis og for skolering av veiledere.
\end{abstract}

Nøkkelord: Veilederutdanning; mentorutdanning; veiledning; veilederroller; mentoring; mentorroller

* Kontakt:

Eli Lejonberg

Institutt for lærerutdanning og skoleforskning

Universitetet i Oslo

E-post: eli.lejonberg@ils.uio.no

\section{Innledning}

Veiledning av studenter og nyutdannede lærere har potensiale til å bidra til at nye lærere blir bedre rustet ved inngangen til det krevende læreryrket (Achinstein, 2006; Caspersen \& Raaen, 2014; Franke \& Dahlgren, 1996; Hobson, Ashby, Malderez \& Tomlinson, 2009; Lindgren, 2005; Smith, Ulvik \& Helleve,

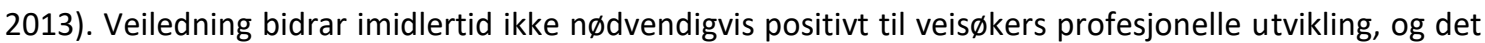
er ingen enighet, hverken blant forskere eller veiledere i skolen, om hvordan veilederrollen helst bør utøves (Hobson et al., 2009; Hobson \& Malderez, 2013; Skagen, 2016). For å bidra til at veiledere skal 
ivareta nye lærere på en hensiktsmessig måte, har man i Norge satset på skolering av erfarne lærere som skal inn i veilederroller (Helleve \& Langørgen, 2010; Ulvik \& Sunde, 2013). Også i internasjonal forskning argumenteres det for at veilederutdanning kan fremme kvalitet i oppfølgingen av nye lærere (Aspfors \& Fransson, 2015; Hobson, Ashby, Malderez \& Tomlinson, 2009). Fra begynnelsen av 2000-tallet ble det etablert studiepoenggivende veilederutdanninger ved flere universiteter og høyskoler i Norge. Fremveksten hadde sammenheng med innføringen av et nasjonalt prosjekt med satsning på veiledning av nyutdannede lærere (Bjerkholt, 2013). I stortingsmelding 11 (2008-2009) formidles en forventning om at lærerutdanningsinstitusjonene skal tilby 30 studiepoengs veilederutdanning. I dag er det en forventning at «praksisveileder bør ha gjennomgått videreutdanning i veiledning på minimum 15 studiepoeng eller forpliktet seg til å starte slik utdanning» (NRLU, 2017 s. 15). Den norske satsingen på veilederutdanning er forholdsvis omfattende sett $i$ et internasjonalt perspektiv (Ulvik \& Sunde, 2013). Imidlertid finner Rambøll $(2015,2016)$ at det er stor variasjon som karakteriserer organisering av og innhold i disse utdanningene.

Funn fra mitt avhandlingsarbeid belyser hvordan veilederutdanning kan utfordre veilederes antakelser om veiledning (Lejonberg et al., 2015). Et hovedfunn fra undersøkelsen indikerte at hvorvidt veiledere hadde fullført 15 studiepoeng fra veilederutdanning hadde betydning for deres oppfatninger om hvordan veilederrollen $b \varnothing r$ ut $\varnothing v e s$. Mer konkret indikerte funnene at veiledere med veilederutdanning i lavere grad rapporterte å mene at det er hensiktsmessig at de som veiledere gir klare tilbakemeldinger og kommuniserer sine vurderinger av veisøkers praksis. Med bakgrunn i slike funn belyser denne artikkelen hva som formidles om utøvelse av veilederrollen i ulike tekster som er antatt å være av betydning for utforming og utvikling av veilederutdanningene i Norge.

Fokuset er på forventninger som formidles i et utvalg av styringsdokumenter, forskning og faglitteratur i norsk kontekst. Det overordnede forskningsspørsmålet er: Hva sies i et utvalg av norske styringsdokumenter, forsknings- og faglitteratur om forventninger til veilederutdanningene om hvordan veileder bør utøve sin rolle? Figur 1 illustrerer en antakelse om mulig påvirkning fra slike skriftlige kilder på utøvelsen av veilederrollen, via veilederutdanningene.

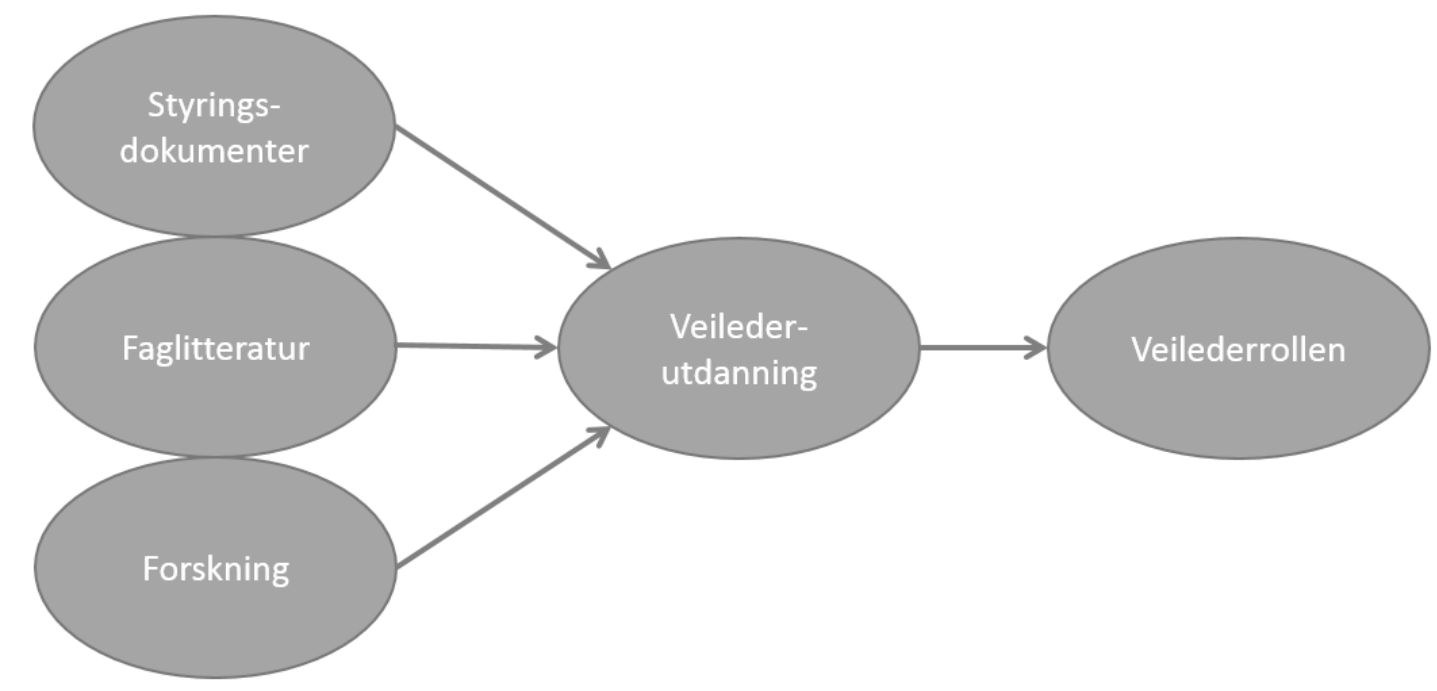

Figur 1. Modellen illustrerer antakelsen om at forventninger uttrykt i relevante styringsdokumenter og forsknings-/faglitteratur påvirker veilederutdanningene og derigjennom ut $\varnothing$ velsen av veilederrollen i praksis. 
Hvordan påvirker veilederutdanningene utøvelse av veilederrollen? En analyse av forventninger uttrykt i styringsdokumenter, forskning og faglitteratur

\section{Teori om veilederrollens og veiledningsbegrepets innhold}

I det norske veiledningsfeltet eksisterer ulike, og til dels kontrasterende tanker, både om hvordan veiledning bør utøves og om veiledningsbegrepets innhold (Bjerkholt, 2013; Skagen, 2016; Østern \& Engvik, 2016). I denne delen vil jeg først tydeliggjøre hvordan ulike forståelser i veiledningsfeltet retter ulike forventninger mot utøvelse av veilederrollen. Menneskers forståelser innen et gitt felt kan beskrives som systemer for tenkning og kunnskap (Lakatos, 1974). Slike systemer for tekning kan fortolkes som ulike paradigmer eller kunnskapssystemer som består av en «hard kjerne» av antakelser og tro (Lakatos, 1974, s. 133). Lakatos (1974) argumenterer for at denne kjernen av antakelser er omgitt av et belte av hjelpende hypoteser som beskytter antakelsene i kjernen mot falsifisering. Jeg vil i det følgende presentere noen slike systemer for tenkning som kan være relevante for å forstå veiledningsfeltet og ulike veilederroller som eksemplifiserer noen typiske veiledningstilnærminger. Begreper som beskriver ulike veilederroller vil brukes i analysen av styringsdokumenter, forskning og faglitteratur.

Slike systemer for tenkning om veiledning kan altså uttrykkes som veilednings-modeller eller -tilnærminger. Eksempelvis presenterer Skagen (2013) ti ulike veiledningsmodeller i sin bok. I denne artikkelen er analysene basert på en inndeling av veiledningstilnærminger, opprinnelig beskrevet av Clutterbuck (2004) og videreutviklet av Mathisen (2015). Tilnærmingene kan tegnes inn i en modell som vist i figur 2. Det er imidlertid verdt å merke seg at inndelingen ikke beskriver gjensidig utelukkende kategorier. Noen veiledere vil veksle ofte mellom ulike tilnærminger og noen vil være mer tro mot én eller få tilnærminger (Clutterbuck, 2004). Dette kommer jeg tilbake til i analysene hvor jeg gjør rede for hvordan ulike kilder retter forventninger om ulike tilnærminger til veiledning.

Figur 2 tar utgangspunkt i a) hvor dirigerende eller bestemmende veileder er i forhold til veis $\varnothing$ ker, og b) i hvilken grad formålet primært er å utfordre veisøkers tenkning eller å støtte veisøkers tenkning:

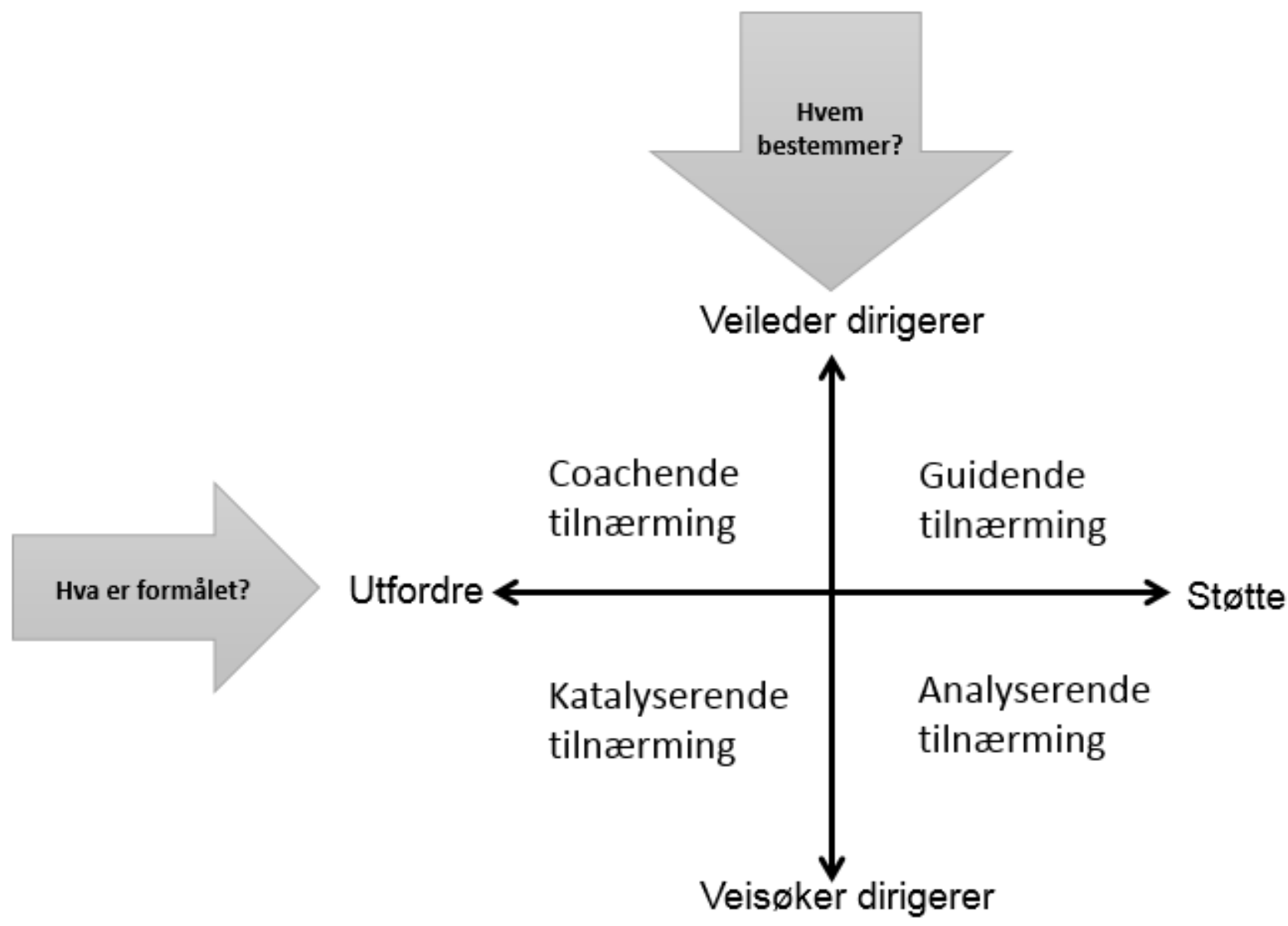

Figur 2. Modellen illustrerer hvordan ulike tilnærminger i veiledning kan deles inn etter veiledningens formål og etter hvor dirigerende veileder og veisøker er. 
De ulike tilnærmingene er delt inn med utgangspunkt i veiledningens formål og aktørenes samhandling. Den loddrette aksen skiller mellom i hvilken grad det er veileder eller veisøker som er mest dirigerende. Dersom samtalen er karakterisert av at veileder bestemmer innhold, anbefaler veis $\emptyset$ ker i en gitt retning eller gir tydelige råd og innspill, er det veileder som er den mest dirigerende. Dersom samtalen i st $\varnothing$ rre grad er karakterisert av at veis $\varnothing$ ker setter agenda og bestemmer veien videre, er det veis $\varnothing$ ker som er mest dirigerende. Den vannrette aksen skiller mellom hva som er hovedformålet med samtalen. Det vil si et skille mellom i hvilken grad samtalen bidrar til å utfordre veisøkers antakelser på den ene siden, og på den den andre siden: i hvilken grad veiledningen kjennetegnes av at veisøker får støtte og oppmuntring.

Clutterbuck (2004) argumenterer for at alle former for veiledning kan plasseres i dette landskapet. Han skisserer videre fire «stiler» som tydeliggjør de ulike tilnærmingene. I den coachende tilnærmingen er det veileder som leder prosessene. Til tross for at veileder utfordrer veisøker til å tenke selv, og til å komme frem til egne svar, er likevel kjennetegnet ved denne tilnærmingen at veileder er dirigerende. Veileder tar gjerne rollen som kritisk venn. Den guidende tilnærmingen er den andre tilnærmingen karakterisert av at veileder er dirigerende. Her kommer veileder selv med svarene og fungerer som rollemodell. I den katalyserende tilnærmingen karakteriseres veiledningen av å utfordre veis $\varnothing$ kers forståelse ved at veileder peker til andre kilder enn veileder og veisøker. Dette kan dreie seg om andre mennesker eller skriftlige kilder som forskning eller skolens planer og retningslinjer for lærere. Veileder fungerer dermed som en katalysator som setter i gang prosesser. I den analyserende tilnærmingen kjennetegnes veiledningen av at veileder st $\varnothing$ tter veis $\varnothing$ kers arbeid med å forstå egen situasjon. Veileder er lyttende, bidrar til at veisøker strukturerer sine tanker og analyser aktuelle situasjoner. Disse fire tilnærmingene tydeliggjøres ytterligere når ulike veilederroller plasseres med utgangspunkt $\mathrm{i}$ de beskrevne tilnærmingene, se figur 3.

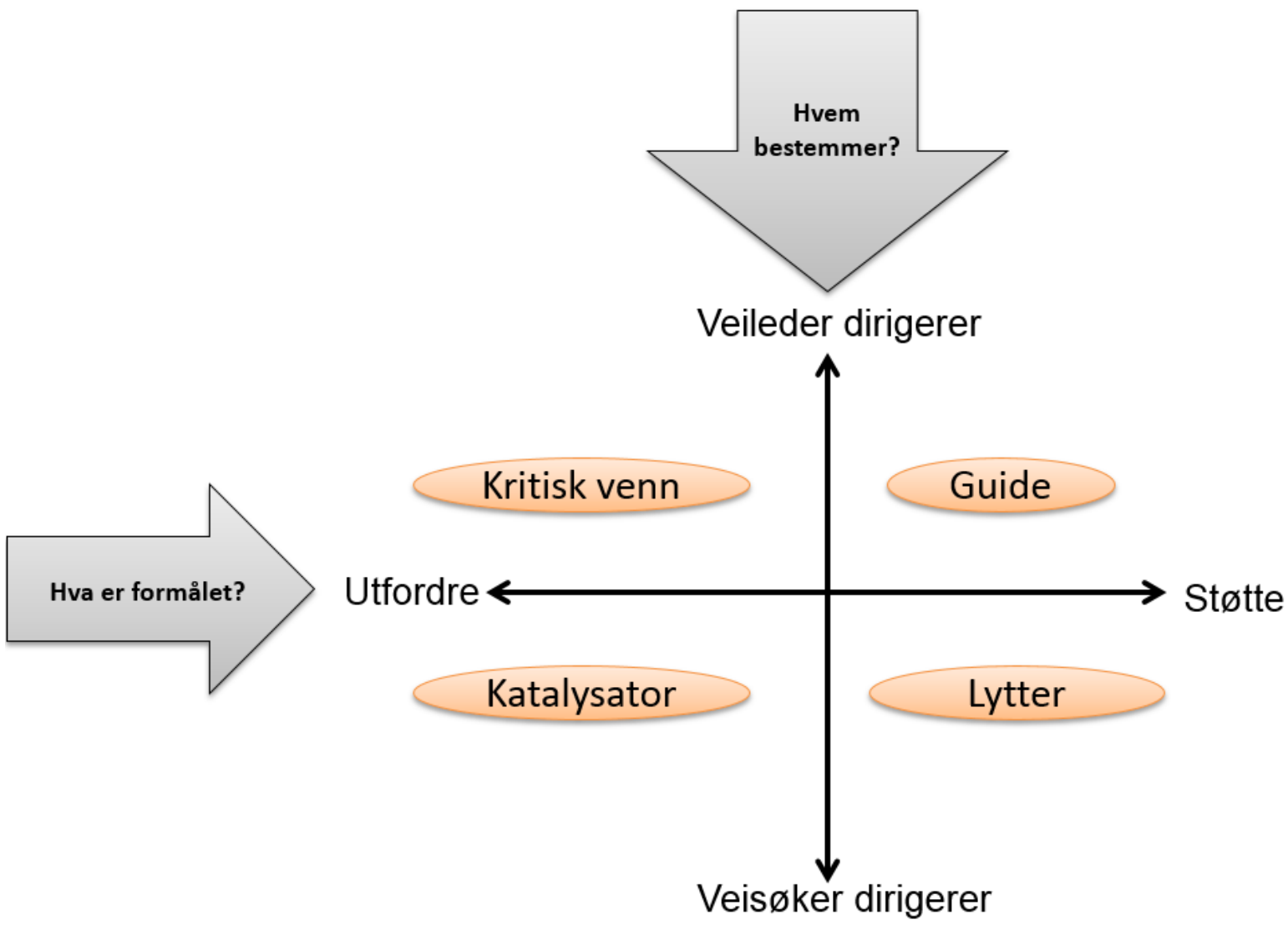

Figur 3. Oversikt over ulike veilederroller med utgangpunkt i karakteristikker ved veiledningen. 
Hvordan påvirker veilederutdanningene utøvelse av veilederrollen? En analyse av forventninger uttrykt $i$ styringsdokumenter, forskning og faglitteratur

En grundigere beskrivelse av veiledningstilnærmingenes roller presenteres i tabell 1. Denne beskrivelsen vil bli anvendt som verkt $\varnothing$ y til å analysere forventninger til veilederutdanningene nedfelt i utvalget av styringsdokumenter, forsknings- og faglitteraturen.

Tabell 1. Typisk atferd og kjennetegn ved de fire veilederrollene.

\begin{tabular}{|c|c|c|}
\hline Veilederrolle & Beskrivelse av veilederatferd & Sentrale rollekjennetegn \\
\hline Guide & $\begin{array}{l}\text { Veileder forteller veisøker hva han/hun } \\
\text { mener kan være hensiktsmessig i ulike } \\
\text { sammenhenger. }\end{array}$ & $\begin{array}{l}\text { Dirigerende rolle. Det primære } \\
\text { formålet er å st } \varnothing \text { tte veis } \varnothing \text { kers tenkning. }\end{array}$ \\
\hline Kritisk venn & $\begin{array}{l}\text { Veileder utfordrer veis } \emptyset \text { kers refleksjon } \\
\text { over eget arbeid og utvikling. }\end{array}$ & $\begin{array}{l}\text { Dirigerende rolle. Det primære } \\
\text { formålet er å utfordre veis } \varnothing \text { kers } \\
\text { tenkning. }\end{array}$ \\
\hline Lytter & $\begin{array}{l}\text { Veileder bidrar til at veis } \varnothing \text { ker } \\
\text { analyserer sin situasjon og sitt arbeid. }\end{array}$ & $\begin{array}{c}\text { Ikke-dirigerende rolle. Det primære } \\
\text { formålet er å st } \varnothing \text { tte veis } \varnothing \text { kers tenkning. }\end{array}$ \\
\hline Katalysator & $\begin{array}{l}\text { Veileder henviser til andre kilder } \\
\text { (eksempelvis forskning eller andre } \\
\text { yrkesut } \varnothing \text { vere) som kan bidra til å } \\
\text { utfordre veisøker. }\end{array}$ & $\begin{array}{l}\text { Ikke-dirigerende rolle. Det primære } \\
\text { formålet er å utfordre veisøkers } \\
\text { tenkning. }\end{array}$ \\
\hline
\end{tabular}

\section{Kontekst: tilnærminger i norsk veiledningstradisjon}

Ideene kjent som handlings- og refleksjonsmodellen har fått stor betydning for hva som har vært ansett som hensiktsmessige tilnærminger til veiledning av nye lærere i Norge (Mathisen \& Bjørndal, 2007; Sundli, 2001, 2002). Strategiene introdusert av Handal og Lauvås (1983) er beskrevet som det «herskende paradigme» i norsk veiledningstradisjon fra 80-tallet og frem til i dag (Skagen, 2013, s. 32). Den harde kjernen (jf. Lakatos, 1974) i dette «paradigmet» uttrykker Handal og Lauvås (1983, s. 14) gjennom sin «hovedtese»: Alle lærere har en «praksisteori» som ligger til grunn for praksis og veiledning må ta utgangspunkt i denne med mål om å «få læreren til bevisst å formulere og utvikle» sin praksisteori. Det er veileders rolle som kritisk venn og lytter som tydeligst karakteriserer denne tilnærmingen til veiledning ettersom veileder skal bidra ved å bevisstgjøre veisøkeren på egne antakelser samt å utfordre antakelsene i veiledning (Handal \& Lauvås, 1983). Imidlertid har flere forskere tatt til orde for at også tilnærminger til veiledning hvor veileder er mer guidende kan være hensiktsmessige (se eksempelvis Kvale, 2007; Skagen, 1998, 2007, 2016; Stålsett, 2006). Flere forskere har dessuten pekt på at veiledere i Norge utøver en eklektisk praksis hvor ulike tilnærminger utøves avhengig av kontekst (Føinum, 2018; Ottesen, 2006; Sundli, 2001, 2002).

\section{Begreper og avgrensninger}

I denne artikkelen er det forventninger ${ }^{1}$ til ut $\varnothing v e l s e$ av veilederrollen som belyses. Med rolle menes uskrevne regler og mønstre for oppførsel og handlemåte som knytter seg til en posisjon (Aubert, 1969). Det er altså forventninger til hva som skal karakterisere veilederrollen som er vektlagt. Ettersom begrepet veiledning gjerne brukes på norsk om veiledning av både nyutdannede, studenter og erfarne lærere, bruker jeg veiledning i denne studien om samhandling mellom en veileder og en veisøker med profesjonell utvikling for veisøker som mål. Jeg har valgt å avgrense til å fokusere på veiledere i skolen, spesielt på veiledere som jobber i ungdomskolen og videregående skole. En veileder er da en relativt erfaren lærer som inngår i veiledningsforholdet for å bidra til veisøkers profesjonelle utvikling, mens en veisøker er en person som inngår i et veiledningsforhold for profesjonell utvikling (Lejonberg, 2016).

Når denne artikkelen tematiserer veilederrollen, omfatter det både veiledning av lærerstudenter og det som tidvis er blitt benevnt mentoring, det vil si veiledning av nyutdannede lærere (Smith, 2018). $\AA$

\footnotetext{
${ }^{1}$ I denne sammenheng er forventninger forstått verbale og non-verbale signaler som utveksles mellom aktører i et fellesskap om å oppføre seg på bestemte måter eller gjøre/ikke gjøre bestemte ting (Bø \& Helle, 2008).
} 
veilede studenter og nyutdannede kan sies å være beslektede fenomener, men ettersom kontekstene for lærerstudenter og nyutdannede lærere er så forskjellige, vil ulike aspekter i veiledningsfaget være aktuelle: Mens studenten praktiserer i veileders klasser (samt at veileder skal være med å vurdere om studenten har tilstrekkelig kompetanse for å jobbe som lærer), veileder mentoren en kollega som (ofte) er nyansatt på en skole, og/eller en kollega på lignende nivå som mentoren selv. En nyutdannet lærer vil - til forskjell fra lærerstudenten - ha selvstendig ansvar for sine elever. Slike grunnleggende forskjeller skaper svært ulike kontekster for veiledning i skolen ${ }^{2}$. Det er imidlertid ingen enighet i Norge i dag om hvorvidt veiledning av studenter og nyutdannede henter sin kunnskap fra så ulike disipliner at veiledere som skal jobbe med lærerstudenter og nyutdannede lærere, bør ta ulike utdanninger. Dermed er noen veilederutdanninger felles for alle som skal veilede nye lærere, mens andre er delt slik at veiledere for henholdsvis studenter og nyutdannede utdannes hver for seg (Rambøll, 2016).

\section{Analyse av styringsdokumenter, forskning og faglitteratur}

Forventinger til veilederutdanningenes tilskrivelse av innhold i veilederrollen fremkommer på forskjellig vis i styringsdokumenter, forskningslitteratur og faglitteratur. I det følgende brukes de introduserte teoretiske begrepene fra tabell 1 , som beskriver ulike veilederroller, til å belyse hvilke forventninger som rettes mot utøvelse av veilederrollen i utvalgte kilder.

\section{Utvalg av kilder}

Når dette skrives, arbeides det med utvikling av nasjonal rammer for veilederutdanning (Utdanningsdirektoratet, 2018). Analysene som her presenteres, er relevant for å forstå hvordan ulike kilder har fremmet forventninger til veilederutdanning og utøvelse av veilederrollen i tiden frem til de nasjonale retningslinjene ferdigstilles. Flere ulike kilder er relevante for å unders $\varnothing$ ke hvilke forventninger som rettes mot veilederrollen. Derfor er styringsdokumenter på nasjonalt nivå som direkte retter forventninger mot veilederutdanningene inkludert i analysene. Et styringsdokument sier noe om politiske intensjoner og ønsket retning på politikken på statsnivå. I denne sammenheng er stortingsmeldinger og nasjonale retningslinjer for veilederutdanninger rettet mot veiledere for nyutdannede spesielt relevante. Det er også de nasjonale retningslinjene for lektorutdanning, ettersom det her skisseres retningslinjer for praksisveiledning av studenter.

«Alle stortingsmeldinger siden 1996 som omhandler lærerutdanning, eller kvalitet i barnehage og skole, har vektlagt betydningen av at nyutdannede lærere får veiledning den første tiden i yrket» (Bjerkholt, 2013, s. 4). To stortingsmeldinger som direkte tematiserer veiledning i oppfølging av nye lærere er inkludert; Stortingsmelding nr. 16 Kvalitetsreformen: om ny lærerutdanning: mangfoldig - krevende relevant (Undervisnings- og forskningsdepartementet, 2002), samt Stortingsmelding nr. 11 Læreren: rollen og utdanningen (Kunnskapsdepartementet, 2009). Den første er spesielt relevant fordi den tematiserer veilederrollen som del av kvalitetsreformen. Den andre er spesielt relevant fordi regjeringen her viste at de ønsket å videreutvikle prosjektet med veiledning for nyutdannede lærere til et nasjonalt system med veiledning for alle nyutdannede lærere i Norge (Bjerkholt, 2013). Når Utdanningsdirektoratet beskriver arbeidet med å utvikle nasjonale rammer for veiledningsordninger og veilederutdanningene, henviser de til en rapport de bestilte fra Rambøll som ble ferdigstilt i 2016 (Rambøll, 2016; Utdanningsdirektoratet, 2018). Ettersom denne rapporten brukes som kunnskapsgrunnlag for arbeidet med å utvikle nasjonale rammer, er den også inkludert i analysen til tross for at det kan diskuteres om en slik rapport passer inn under definisjonen styringsdokument. Rapporten fra Rambøll sammenstiller tilgjengelig forskning samt presenterer funn fra egne undersøkelser, og er ment som beslutningsgrunnlag for politiske avgjørelser om veiledningsordninger og veilederutdanninger (Rambøll, 2016).

\footnotetext{
${ }^{2}$ I tillegg er det i Norge i dag mye fokus på kollegaveiledning eller skolebaserte utviklingsprosjekter hvor også erfarne lærere skal veiledes til profesjonelle utvikling (Lejonberg, Dahl \& Brovoll, akseptert). Det er imidlertid veiledning av studenter og nyutdannede som er fokus i denne artikkelen.
} 
Hvordan påvirker veilederutdanningene utøvelse av veilederrollen? En analyse av forventninger uttrykt $i$ styringsdokumenter, forskning og faglitteratur

Videre er forskning på veilederutdanninger inkludert. For å begrense omfanget er fokus på doktorgradsavhandlinger som tematiserer utøvelse av veilederrollen og veilederutdanning. Også annen fagfellevurdert forskning som direkte tematiserer veilederutdanning i Norge er inkludert. Slike tekster er relevante fordi de retter forventninger mot veilederutdanningene, samtidig som slik forskning også utgjør pensum i veilederutdanningene. Dermed er det grunn til å anta at de også kan bidra til å påvirke veilederes forståelse for veilederrollen direkte (Bjørndal, 2008). Pensum i veilederutdanningene består også av faglitteratur som ikke presenterer empiriske undersøkelser. Basert på antakelsen om at litteratur om rolleutøvelse i veilederutdanningene kan påvirke rolleutøvelsen, inkluderes også slik faglitteratur i analysen. Valget av faglitteratur som er belyst i dette bidraget, er basert på Rambølls $(2015,2016)$ gjennomgang av pensumlistene til veilederutdanningene i Norge. Rambøll undersøkte hvilke forfatternavn som går igjen på litteraturlistene, og fant at Handal og Lauvås forekommer hyppig. Noen klar nummer to ble ikke funnet, og pensumlistene preges for $\emptyset$ vrig av stor variasjon. Det er derfor bidrag fra Handal og Lauvås som trekkes frem her.

\section{Analyse av kilder}

Tekster har betydning for hvordan vi opplever verden og hvordan vi handler. Fremstilling av et fenomen $\mathrm{i}$ tekst antas dermed å være relevant for å forstå hvordan fenomenet forstås i en kontekst (Fitzgerald, 2012; Silverman, 2011). I denne sammenheng vil det si at fremstillingen av veilederrollen $i$ de valgte kildene antas å være relevant for å forstå hvilke forventninger til veilederrollen som fremmes. Å bruke kategorier på en slik måte har til hensikt å skape ny forståelse av et materiale (Fitzgerald, 2012; Robson, 2002). Særlig har spørsmål som «hva er inkludert?» og «hva er utelatt?» vært førende for analysene av hvordan de ulike veilederrollene kan sies å gjenspeiles i de valgte kildene (Silverman, 2011, s. 239). For å belyse problemstillingen er en kvalitativ innholdsanalyse gjort for å kartlegge hvordan forventninger til utøvelse av veilederrollen fremkommer i kildene. Kildene er analysert med utgangspunkt i det teoretiske rammeverket som ble skissert i tabell 1. Ved første gjennomlesning fokuserte jeg på formuleringer hvor det ble beskrevet forventninger rettet mot veilederutdanning og ut $\varnothing$ velse av veilederrollen. Søkeordene veileder, veilede, veiledning, mentor og mentoring ble også brukt for å søke opp de relevante delene av dokumentene. Deretter ble veilederrollene som er presentert i det teoretiske rammeverket brukt som utgangspunkt for en kategorisering av hvilke forventninger til rolleutøvelse som vektlegges i kildene. Det er altså fokus på hvordan tekstene reflekterer, og potensielt influerer, virkeligheten som er i fokus (Silverman, 2011). Intensjonen med denne fremgangsmåten er å bruke teoretiske kategorier til å belyse hvordan veilederrollen fremstilles og beskrives i de relevante kildene. Jeg har valgt kilder som er antatt å være sentrale formidlere av forventninger rettet mot veilederrollen og veilederutdanningene. Intensjonen er altså ikke å gi helhetlig bilde av hva som finnes på pensumlistene i norske veilederutdanninger ${ }^{3}$.

\section{Forventninger og veilederroller i ulike kilder}

\section{Styringsdokumenter}

\section{Nasjonale retningslinjer for veilederutdanning}

De nasjonale retningslinjene for skolering av dem som skal veilede nyutdannede lærere, skisserer tema som skal inngå i veilederutdanning samt læringsutbyttebeskrivelser (GNIST, 2010). Temaene er: (a) veiledning, kommunikasjon og samspill, (b) læring og lærerarbeid, (c) organisasjon, kultur og innovasjon og (d) profesjonskunnskap. I de påfølgende beskrivelsene vektlegger retningslinjene at (a) og (b) skal bli «belyst» og "kritisk analysert» i veilederutdanning (s. 5). Det er altså ingen tydelige forventninger til

\footnotetext{
${ }^{3}$ Andre har bidratt med kunnskap om dette, se eksempelvis $\emptyset$ strem og Hanssen, 2018.
} 
ut $\varnothing$ velse av veilederrollen som trekkes frem her, forventningene er heller rettet mot utvikling som skal skje i veilederstudentene. Når det gjelder (c) og (d) derimot, står det at tematiseringene som trekkes frem, skal «danne et utgangspunkt for kritisk analyse og refleksjon i veiledning» (s. 5). At man i veilederutdanning skal analysere og reflektere kritisk over aspekter som organisasjon, kultur, innovasjon og profesjonskunnskap for å bidra til kritisk analyse og refleksjon i veiledning, indikerer en veilederrolle hvor veileder ved å være lyttende, kritisk og utfordrende bidrar til veisøkers refleksjon, altså en rolle som lytter og kritisk venn.

Læringsutbyttebeskrivelsene inneholder noen utsagn om av hva studentene skal oppnå kunnskap om og kompetanse $i$ uten at det pekes mot hvordan denne kunnskapen skal brukes. Det er imidlertid også beskrivelser som kommuniserer forventninger til utøvelse av veilederrollen. Eksempelvis er det beskrevet at veilederstudentene skal oppnå ferdigheter i å «kritisk analysere og diskutere veiledning, kommunikasjonsprosesser og læringsprosesser», som igjen peker mot en rolle hvor veileder legger til rette for veisøkers utvikling ved å innta en lyttende holdning og/eller å gå inn i rollen som kritisk venn (s. 4). Det er imidlertid også to formuleringer i læringsutbyttebeskrivelsene som åpner for mer mangefasettert veilederrolle. Formuleringen om at fullført utdanning skal bidra til studentenes ferdigheter i å «st øtte og utfordre de nyutdannede lærerne på de sakene, temaene eller utfordringene de nyutdannede ber om veiledning på» åpner for ulike tilnærminger til veilederrollen (s. 4). Veileder kan støtte og utfordre ved å guidende fortelle om egne erfaringer eller uttrykke meninger, ved å peke mot andre kilder (som katalysator), lytte til veisøkers beskrivelser og/eller ved å stille utfordrende spørsmål som kritisk venn. Formuleringen om at veiledere skal utvikle kompetanse i å «vurdere og bruke relevante forskningsresultater som grunnlag for en kvalifisert veiledning» åpner også for et bredt spekter av strategier og veilederroller ettersom ulik forskning indikerer at ulike veilederroller kan være nyttige. Dette vil jeg komme tilbake til når jeg skriver mer om ulike forskningsbidrag. Det er også interessant å merke seg formuleringen om at veiledere skal utvikle kompetanse til å kunne reflektere over «veiledning som bidrag til innovasjon og fornyelse» i skolens virksomhet. Dette kan forstås som en forventning om av veiledere også skal engasjere seg i utviklingsprosjekter som strekker seg utover det å støtte nye lærere (s. 4). En slik utvidelse av veileders rolle og ansvarsoppgaver er drøftet i Lejonberg et al. (akseptert).

\section{Nasjonale retningslinjer for lektorutdanning for trinn 8-13}

De nasjonale retningslinjene for lektorutdanning understreker hvor viktig det er at veiledere for lærerstudenter i praksis «skal ha gjennomgått videreutdanning i praksisveiledning på minimum 15 studiepoeng eller forpliktet seg til å starte opplæring i praksisveiledning» (Kunnskapsdepartementet, 2013 , s. 15). Retningslinjene som skisseres her er lite kokrete i sine forventninger til ut $\varnothing v e l s e$ av veilederrollen, og de åpner dermed også i større grad for tolkning. Eksempelvis står det at veiledere «må (også) ha FoU-kompetanse» (s. 15). Det fremkommer imidlertid i liten grad forventninger som belyser hvorfor FoU-kompetanse er viktig, eller hvordan denne kompetansen skal brukes i utøvelse av veilederrollen. Dermed åpner formuleringen for et stort tolkningsrom. En mulig tolkning er at veileder kan bistå veisøker i deres FoU-arbeid ved å være en kritisk venn. I rollen som kritisk venn kan veileder utfordre veisøkere ved å stille dem spørsmål som får dem til å reflektere over, og dermed muligens utvikle, egen praksis. Også i rollen som aktiv lytter vil veileder kunne bidra til at veisøker setter ord på egne antakelser og utforsker egen praksis. Imidlertid kan veileder også i rollen som guide eller katalysator bidra til nye tanker om praksis som kan utvide veisøkers forståelse og handlingsrepertoar. Eksempelvis kan dette skje ved at veileder kommunisere sine perspektiver eller ved å bidra til å knytte erfaringer fra praksis til teori. Slike innspill kan være nyttige for veisøkers FoU-arbeid både når fokus og teoriforankring for utviklingsarbeidet skal bestemmes og testes ut, og når nye tilnærminger i praksis skal prøves ut og evalueres.

\section{Ramb $\varnothing$ lls kartlegging av veiledningsordningen}

I kartleggingsarbeidene til Rambø|l $(2014,2015,2016)$ rettes søkelyset mot veiledere som gjennomf $\varnothing$ rer veilederutdanning. I arbeidet beskrives funn som tyder på at «de 'utdannede' veilederne (...) har en 
Hvordan påvirker veilederutdanningene utøvelse av veilederrollen? En analyse av forventninger uttrykt $i$ styringsdokumenter, forskning og faglitteratur

rolleforståelse som er mer i tråd med det forskningen fremhever som god veiledning», og indikasjoner på at «veilederutdanningen utgjør en positiv forskjell» (Rambøll, 2015, s. 3). De beskriver altså, som Lejonberg et al. (2015), at det å ta veilederutdanning bidrar til at veiledere endrer syn på hvordan veilederrollen bør utøves. Rambøll (2015) beskriver «veilederutdanningen bidrar til å endre synet på veilederrollen og utøvelsen av denne» (s. 99). Dermed blir det svært interessant å undersøke hvilke syn på veilederrollen som legges til grunn når Rambøll (2015) hevder at endringen er «positiv» eller «mer i tråd med det forskningen fremhever som god veiledning» (s. 3). De beskriver hvordan de forstår hensiktsmessig utøvelse av veilederrollen: «God utøvelse av veilederrollen handler med andre ord om å gi veisøker mulighet til selv å resonnere seg frem til ulike løsninger på et problem. Videre trekker flere frem at veilederen har en viktig rolle i å bistå veisøker med å utvikle en egen læreridentitet og at veileder ikke skal overføre egne vurderinger av god undervisningspraksis» (s. 78). Forventningene som formidles her er nokså tydelige i retning av å fraråde en guidende rolleutøvelse. Rollen som kritisk venn og lytter kommer til uttrykk i formuleringer som understreker viktigheten av at veisøker selv skal «resonnere seg frem til ulike løsninger på et problem» understrekes (s. 78). Tilsvarende forventninger om å være lyttende og spørrende i større grad enn rådgivende tydeliggjøres også i hovedrapporten fra 2016: «En veileder som har en god og klar forståelse av sin rolle og sitt arbeid, vil kunne gi en mer åpen og fordomsfri veiledning, enn en som har en mer begrenset bevissthet. En fare ved å være lite bevisst og avklart, er at (...) veileder legger for mye av sine egne overbevisninger i veiledningen av den nyutdannede, og fremstår mer som en rådgiver» (Rambøll, 2016, s. 44).

\section{Stortingsmelding nr. 16 (2001-2002)}

De undersøkte stortingsmeldingene inneholder nokså åpne formuleringer. Dette åpner for flere tolkninger av hvilke forventninger meldingen antyder når det gjelder veilederrollen. For eksempel understrekes det også her hvor viktig det er at veiledere har FoU-kompetanse, men uten at det fremkommer klare føringer for veiledning: «Lærerutdanningsinstitusjonene må intensivere sitt arbeid med FoU-strategier» (s. 66). Om veiledning står det at «erfaringene så langt er at systematisk veiledning er en god hjelp til å reflektere over egen praksis i et noe videre perspektiv. De nyutdannede får hjelp til å «realisere noen av sine tanker om lærergjerningen knyttet opp til arbeid i egen klasse» (s. 58). At veisøker skal realisere sine tanker antyder en forventning om at veileder skal bidra til veis $\varnothing$ kers refleksjon over handling. En slik tilnærming er tydeligst forankret i veilederroller som lytter og kritisk venn. Formuleringen «en veiledning hvor en drøfter egne og andres erfaringer og ser disse i sammenheng med den teorien en tidligere har hatt, vil gjøre læringen mer personlig og varig» (s. 58), åpner for en mer mangefasettert rolle ettersom hvilke teoretiske bidrag eller erfaringer som vektlegges i veiledningen vil ha betydning for hvilke veilederroller som er $\mathrm{i}$ fokus. Formuleringen kan forstås som nokså åpen ettersom "andres erfaringer» her kan tolkes som om dette også innbefatter veileders erfaringer, hvilket i så fall kan sies å åpne for en mer guidende veilederrolle. Vektleggingen av teoretisk forankring kan også forstås som en forventning om at veileder fungerer som katalysator ved å introdusere teori som forankring for diskusjoner eller eventuelle anbefalinger.

\section{Stortingsmelding nr. 11 (2008-2009)}

Stortingsmelding nr. 11 gir et lignende bilde som skissert over. Formuleringen, «praksisnærhet og kritisk refleksjon over praksiserfaringene er kjerneelementer i lærerkvalifiseringen. Obligatorisk veiledet praksis betraktes derfor som en svært viktig del av lærerutdanningen» (s. 66), peker mot forventninger om at veileder skal stimulere veisøkers refleksjon. At uttrykket «kritisk refleksjon» skal kjennetegne "obligatorisk veiledet praksis» kan tolkes i retning av forventninger til veileder skal opptre i rollen som kritisk venn og lytter slik at veileder legger til rette for at veisøker setter ord på egne erfaringer, refleksjoner og opplevde utfordringer. Samtidig uttrykker Stortingsmeldingen også forventninger som åpner for en mer mangefasettert veilederrolle: «Nyutdannede lærere trenger likevel trening og veiledning i å håndtere den praktiske delen av læreryrket» (s. 31). Veileder kan bidra til veis økers håndtering av de praktiske sidene ved yrket ved å utfordre antakelser eller få veisøker til å sette ord på praksisutfordringer 
og oppfatninger om praksis. At begrepet trening er brukt kan imidlertid forstås som en åpning mot en mer guidende tilnærminger hvor veisøker kommer med forslag og forklarer med utgangspunkt i praksis. Også denne Stortingsmeldingen inneholder formuleringer om at veilederes kjennskap til FoU-arbeid er viktig, men uten en tydelig sammenkobling til veilederroller: «Pedagogikklærerne må samarbeide med fag- og praksislærere om undervisning, praktiske oppgaver og FoU-prosjekter der teori og praksis kan møtes» (s. 20). I lys av mine fortolkninger, formidler de to unders $\varnothing$ kte stortingsmeldingene tydeligst forventninger om at veiledere skal fungere som kritiske venner og i lyttende roller. Imidlertid er det flere formuleringer i disse styringsdokumentene som åpner for utøvelse av en sammensatt veilederrolle, som trekker på flere av vektleggingene som beskrives i tabell 1.

\section{Forskning}

Hva forteller så forskningen oss om fokus i veilederutdanningene og veilederroller? Aspfors og Fransson (2015) presenterer en metaanalyse hvor de har undersøkt kvalitativ forskning på veilederutdanning internasjonalt. I lys av de forskningsbidragene disse forfatterne har analysert, konkluderer de med å understreke «the significance of mentors' critical thinking, reflective og analytical skills. (...) helping others to analyse and develop their teaching. Most importantly, they are prepared to challenge taken for granted assumptions» (s. 83). De finner altså at kritisk tenkning, refleksjon og analyse, vektlegginger som kjennetegner kritisk-venn-rollen, understrekes i kildene de har unders $\varnothing$ kt. Dessuten argumenterer de for at det er viktig at veileder har et slikt fokus. Når de understreker at veileder skal hjelpe andre å analysere sin praksis, indikerer det også en veilederrolle hvor det er viktig å være lyttende slik at veisøker får satt ord på sine tanker. I flere studier nevnes det at dette fokuset står sterkt i norsk veiledningstradisjon. Eksempelvis skriver Bjerkholt (2013) om informantene hun har unders $\varnothing \mathrm{kt}$ i sitt doktorgradsarbeid at de har bakgrunn fra en veilederutdanning som var «preget av en tilnærming til veiledning som vektlegger refleksjon over handling» (s. 85-86), hvilket også indikerer at veileder har en viktig rolle som den som bidrar til at veisøker setter ord på og utforsker egen praksis. Bjørndal (2008) unders $\varnothing$ kte i sitt doktorgradsarbeid asymmetri og symmetri i veiledningssamtaler. Han finner at «veiledere streber mot idealer om symmetri i sine samtaler», og at dette er spesielt karakteriserende for «veiledere som har lest veiledningslitteratur, og som i tillegg tar videreutdanning i veiledningspedagogikk» (s. 649). Et fokus på symmetri indikerer en veilederrolle hvor veileder heller stiller spørsmål og er åpen for mange ulike svar, enn en mer guidende rolle hvor veileder kommer med klare innspill på hvordan praksis kan eller bør ut $\varnothing$ ves. Helleve og Langørgen (2010) skriver at «refleksjon er fundamentet i vår veilederutdanning» (s. 179). Videre argumenterer de for at et av målene i veilederutdanningen må derfor være å bli bevisst på hvordan man som veileder kan legge til rette for ulike kontekster som kan «fremme refleksjon, for nye lærere så vel som erfarne» (s. 180). Fokus på refleksjon vektlegges i rollene som kritisk venn og lytter. Sundli (2002) skrev, med bakgrunn i sitt avhandlingsarbeid, at «strategien i På egne vilkår utgjør ekspertteknikken som garanterer profesjonalitet» for veiledere, og at strategien har en «dominerende plass» i studieplaner, terminologi og eksempler i skolering av veiledere (s. 112). Det vil si at en spørrende og lyttende veilederrolle beskrives som dominerende og som hensiktsmessig.

Også undersøkelser fra mitt avhandlingsarbeid indikerer at veiledere i veilederutdanning er svært opptatt av å bidra til veisøkers refleksjon. På en skala fra 1 til 7 svarte 146 veiledere hentet fra veilederutdanninger over hele Norge i snitt 6,8 på en påstand om at det er «svært viktig at den jeg veileder, får anledning til å reflektere over egen praksis» i veiledningssamtaler (Lejonberg, 2016). Også slike funn indikerer at norske veiledere er opptatt av å lytte og av å bidra til veisøkers refleksjon. I Lejonberg et al. (2015) finner vi at veilederutdanning utfordrer veilederes antakelser om hva som kjennetegner god veiledning. Nærmere bestemt indikerer resultatene at de som har fullført veilederutdanning, har mindre tro på at det er hensiktsmessig å innta en rolle karakterisert av klare tilbakemeldinger og å kommunisere egne meninger, hvilket altså kjennetegner en guidende veilederrolle.

Til sammen tydeliggjør disse eksemplene at fokuset på veisøkers refleksjon og en spørrende, åpen og lyttende veilederrolle står sterkt i forskning som har formet norsk veiledningstradisjon og skolering av veiledere. I lys av de fire veilederrolle-kategoriene viser analysen en tydelig vektlegging av den lyttende 
Hvordan påvirker veilederutdanningene utøvelse av veilederrollen? En analyse av forventninger uttrykt $i$ styringsdokumenter, forskning og faglitteratur

veilederrollen, hvor veileders intensjon er å bidra til at veisøker reflekterer over og analyserer egen situasjon. Også rollen som kritisk venn kommer tydelig til uttrykk $i$ analysene $i$ formuleringer som vektlegger at veileder skal bidra til veisøkers utvikling ved å spørre etter begrunnelser for konkrete handlingsvalg i undervisning (refleksjon over handling), eller ved å utfordre veisøkers teoretiske antakelser om eksempelvis undervisning og læring.

Andre forskere har imidlertid argumentert for en mer variasjonsrik veilederrollepraksis. Skagen (1998, 2016) har beskrevet endringer innenfor norsk veiledningspraksis hvor modell-læring og handling er blitt nedtonet til fordel for veiledning skjermet fra annen yrkesutøvelse med fokus på refleksjon. Han argumenterer for at veiledere i Norge med fordel kan «la seg inspirere av flere modeller og teorier» (Skagen, 2016 s. 77). Smith (2016) trekker frem en sammensatt veilederrolle når hun beskriver profesjonskunnskap for mentorer. Hun peker på evne til å artikulere egen praksisteori, gi gode tilbakemeldinger, bygge bro mellom teori og praksis, modellere god undervisning, og å bidra til systematisk refleksjon og kommunikasjonskompetanse. Også Ulvik og Sunde (2013) poengterer en utvidet veilederrolletypologi i sin beskrivelse av funn fra egen forskning på veilederutdanning. De sier det slik: "experiences and know-how turned out to be necessary but not sufficient to perform as a professional mentor» (s. 767), et utsagn som indikerer at det er viktig at veiledere kan vise og forklare, men også bør kunne bidra på andre måter overfor veisøker. Egne funn (Lejonberg \& Tiplic, 2016) indikerer at en veilederrolle karakterisert av det å gi råd og å kommunisere sine meninger, altså en mer guidende rolle også kan være hensiktsmessig. En annen studie viser at lærerstudentenes ønske om å få klare tilbakemeldinger $i$ veiledning er positivt assosiert med tro på egne evner (Lejonberg, 2018). Funnet indikerer at lærerstudenters profesjonelle selvtillit $\mathrm{i}$ lærerrollen kan være av betydning for hvor mottakelige man er for veilederes innspill. Studentenes vurdering av tillit og trygghet $i$ veiledningsforholdet er imidlertid negativt assosiert med tro på egne evner. På bakgrunn av slike funn kan man argumentere for at veileder må kjenne til ulike strategier og metoder for å kunne tilpasse veiledningen til studentenes behov.

\section{Faglitteratur}

Rambøll (2015) finner som nevnt at forfatterne Handal og Lauvås er de som er representert på flest pensumlister ved norske veilederutdanninger. I boka På egne vilkår, som utkom i 1983 i Norge og 1982 i Sverige, argumenterer Handal og Lauvås for at veiledningens mål er å «få læreren til bevisst å formulere og utvikle» sine antakelser (Handal \& Lauvås, 1983, s. 14). I en publikasjon fra 1990 videreutviklet forfatterne denne tenkningen med tydeligere å utfordre læreres antakelser om læring og undervisning. Hensikten uttrykkes eksplisitt: «Ved å bli mer klar over egen yrkeskunnskap, øker mulighetene for å endre og utvikle kunnskapsbasen» (Lauvås \& Handal, 1990 s. 45). Disse antakelsene og rådene om hvordan veiledning av lærere bør skje, er blitt kjent som handlings- og refleksjonsmodellen og har altså hatt stor innflytelse på skoleringen av veiledere i Norge (Bjerkholt, 2013; Lejonberg, 2016; Mathisen \& Bjørndal, 2007; Skagen, 2013, 2016). I lys av de fire rolletypene i Tabell 1 ligger denne veilederstilen nærmest kritisk venn og lytter da den vektlegger det å utfordre veisøker og å få veisøker til å sette ord på sine antakelser.

Retter så Handal og Lauvås noen forventninger til veilederutdanningene i sine tidlige publikasjoner? I Lauvås og Handal (1990) understreker de at det er «all grunn til å fremheve (...) nødvendig veilederkompetanse» (s. 51). De hevder også at det er «faktisk så stor avstand mellom den veiledning som 'ufaglærte' driver og den som drives av skolerte, erfarne veiledere, at det nesten er snakk om ulike former for virksomhet» (Lauvås \& Handal, 1990 s. 26). Det presenteres imidlertid ingen empiri som evidensgrunnlag for påstanden eller som konkretiserer hvordan ulike grupper veiledere skiller seg fra hverandre. Etter hvert som teorien presentert av Handal og Lauvås ble kjent, ble den såkalte handlingsog refleksjonsmodellen et viktig grunnlag for å utvikle veilederkompetanse. I 1999-utgaven av På egne vilkår hevder forfatterne at «svært mange lærere som i dag arbeider som veiledere/øvingslærere i lærerutdanning, har en veilederutdanning (av varierende omfang) bak seg, noe som i de fleste tilfeller vil bety at de (også) har fått kjennskap til den veiledningsstrategien som vi presenterer her» (s. 151). Med utgangspunkt $\mathrm{i}$ veilederrollene som ble presentert innledningsvis, er det altså et tydelig fokus på rollen 
som kritisk venn og lytter som fremheves i bidragene fra Handal og Lauvås. De beskriver også hvordan kjennskap til disse veiledningsstrategiene oppnås via veilederutdanning.

\section{Oppsummering}

Analysene viser altså at forventninger om ulike veilederroller kommer til uttrykk i de ulike undersøkte kildene. Det er også variasjon når det gjelder i hvilken grad ulike forventninger fremmes i de ulike kildene. I figuren under er dette illustrert ved å presentere kilder hvor en gitt veilederrolle fremkommer tydelig med mørk lilla og kilder hvor en gitt veilederrolle fremkommer mindre tydelig med lys lilla.

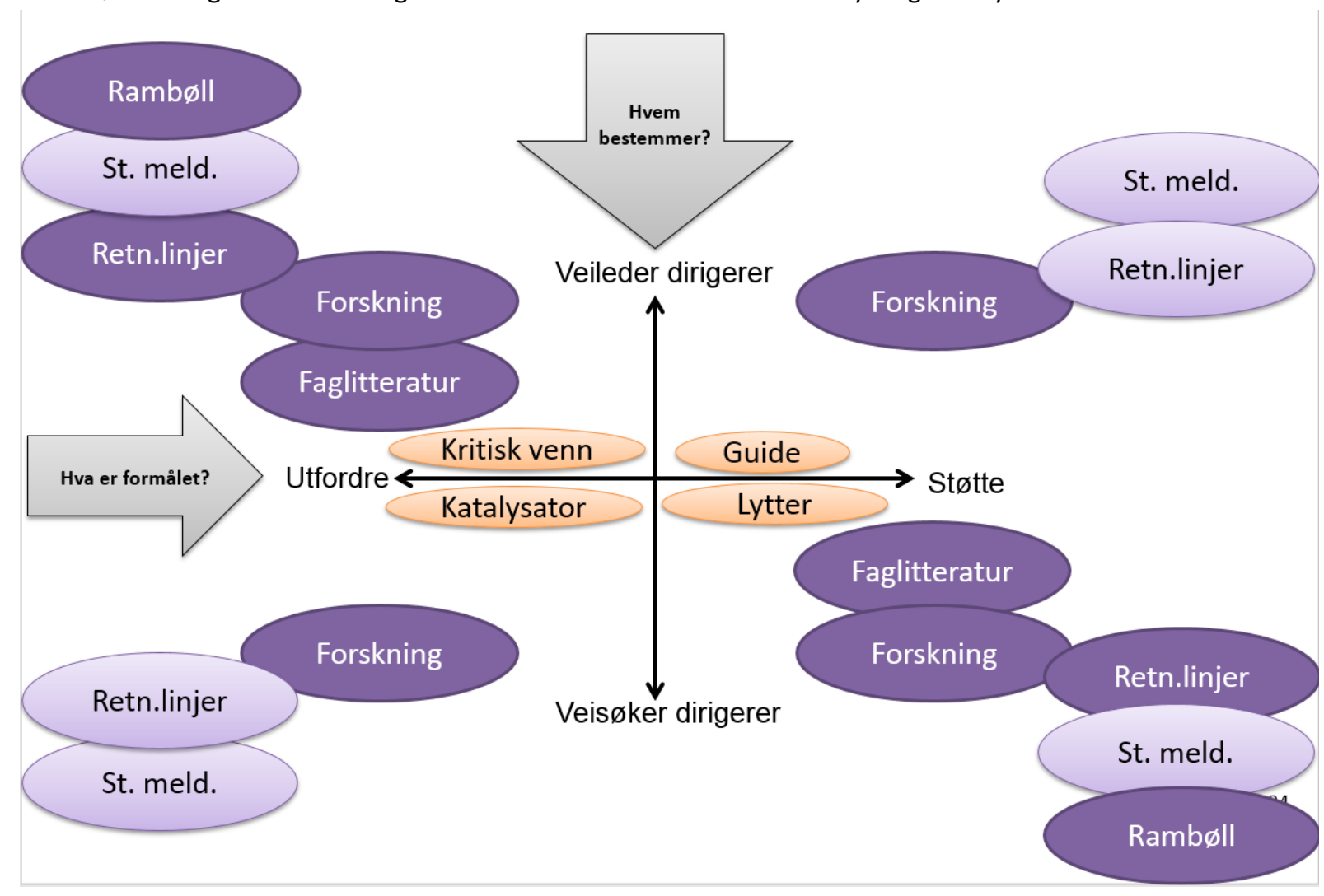

Figur 4. En oversikt som illustrerer fokus på ulike veilederroller i undersøkte kilder.

De retningslinjene som har foreligget for veilederutdanning og utøvelse av veilederrollen i lærerutdanning til nå uttrykker tydelige forventninger om at veiledere skal være lyttende og fungere som kritisk venn. Dette kommer til uttrykk i formuleringer om eksempelvis at veisøkers refleksjon og egen utforskning skal vektlegges i veiledning. Imidlertid åpnes det også for andre veilederroller i mindre spesifikke formuleringer om at forskning skal vektlegges og at FoU-kompetanse er viktig. Analysene indikerer videre at stortingsmeldingene uttrykker vage forventninger til rolleutøvelse og dermed åpner for en bred tilnærming til veilederrollen. Rambølls rapporter er viktige i det pågående arbeidet med utvikling av nasjonale rammer for veiledning. I disse rapportene argumenteres det, som vist, for at veilederutdanning er viktig for at veiledere skal utvikle en rolleforståelse hvor roller som lytter og kritisk venn vektlegges. At Rambøll er så tydelige i å rette forventninger mot veilederrollen kan imidlertid problematiseres i lys av forskning på feltet. I forskning presenteres funn som indikerer hvordan ulike veilederroller kan være hensiktsmessig. Dermed formidler forskning ulike og til dels kontrasterende anbefalinger for skolering av veiledere. Forskningen er også representert som faglitteratur (det vil si som pensum) i landets veilederutdanninger. I den faglitteraturen som ikke er kategorisert som forskning i denne analysen er fokuset på veilederroller som vektlegger veiledning karakterisert av rollene lytter og kritisk venn tydeligst. 
Hvordan påvirker veilederutdanningene utøvelse av veilederrollen? En analyse av forventninger uttrykt $i$ styringsdokumenter, forskning og faglitteratur

\section{Diskusjoner og konklusjoner}

De presenterte analysene indikerer altså en vektlegging av veilederrollene lytter og kritisk venn i norsk kontekst. Selv om forskning tydeliggjør at et bredere spekter av tilnærminger kan være hensiktsmessig, er det altså nettopp den lyttende og kritisk utfordrende veilederrollen som tradisjonelt er blitt vektlagt i faglitteraturen og i veilederutdanningene til nå, som tydeligst fremkommer i gjeldende styringsdokumenter og i rapportene som legges til grunn for arbeidet med nasjonale rammer. Det kan problematiseres at forventninger om at veiledere skal være lyttende og innta rollen som kritisk venn vektlegges i ulike kilder som retter forventninger mot veilederrollen og veilederutdanning.

Forskning på veilederutdanning indikerer, som vist, at gjennomført veilederutdanning i Norge ser ut til å bidra til at veiledere i større grad vektlegger rollene som lytter og kritisk venn enn andre vektlegginger i ut $\varnothing$ velsen av veilederrollen. Slike funn kan sies å indikere at veilederutdanning «virker» i den forstand at veilederutdanningene har bidratt til å påvirke oppfatninger om hvordan veilederrollen bør utøves, i overenstemmelse med de ideer om veiledning som har stått sterkt. Imidlertid åpner retningslinjer som er relevante for skolering av veiledere for en bredere tilnærming til hvordan veiledere kan og bør utøve sin rolle. Dette fremkommer særlig ved formuleringer som ikke trekker frem tydelige forventninger til hvilke karakteristikker veilederrollen skal utvikles i overenstemmelse med. Også i stortingsmeldinger åpnes det for veilederroller som karakteriseres av ulike tilnærminger til veiledning.

I Rambølls utredninger er det formuleringer som kopler veilederes rolle ut $\varnothing$ velse til "god veiledning» (Rambøll, 2015, s. 3). I rapporten argumenteres det for at veilederutdanning har hensiktsmessig påvirkning på veilederes rolleutøvelse. En forståelse av god veiledning som veiledning hvor veileder er lyttende og inntar rollen som kritisk-venn legges da til grunn. Ideene om at veilederes viktigste rolle er å lytte og stille utfordrende spørsmål som har stått sterkt i Norge siden 1980-tallet, legges dermed til grunn for det videre arbeid med å utvikle nasjonale retningslinjer for veiledning av nye lærere i Norge. Dette er problematisk, ettersom det, som vist, finnes evidensgrunnlag for å hevde at ulike tilnærminger til veilederrollen kan være hensiktsmessig, også tilnærminger hvor veileder viser egen praksis, gir konkrete råd og uttrykker sine tanker om veisøkers praksis. Slike funn kan brukes som argument for at veilederutdanningene bør presentere sine studenter for et mangfold av mulige roller og måter å veilede på.

\section{Begrensninger og implikasjoner for videre forskning}

En relevant begrensning ved denne studien knytter seg til det teoretiske rammeverket som er skissert innledningsvis og brukt i analysene av de kildene som danner grunnlag for å belyse hvilke forventninger som rettes mot utøvelse av veilederrollen. Figur 3 som deler veilederrollene inn etter hvem som er mest bestemmende i veiledningen og eller hva som er det primære formålet i veiledningen til enhver tid er, som alle modeller, en forenkling av virkelighetens kompleksitet. Slike forenklinger kan være gunstige for å bidra til økt forståelse av komplekse mekanismer, men det vil alltid være nyanser i det empiriske materiale som kan overses. En implikasjon er at man i framtidig forskning bør studere mekanismer i kommunikasjonen mellom veisøker og veileder som overskrider den grovskissen som er presentert $\mathrm{i}$ denne artikkelen. Det er liten tvil om at kompleksiteten som kjennetegner utøvelse av veilederroller ikke rettferdiggjøres av slike modeller. Eksempelvis kunne de presenterte veilederrollene også vært plassert andre steder i modellen; en guidende tilnærming i veiledning kan klart utfordre veisøker, spesielt dersom veileder kommuniserer helt andre synspunkter eller praksiser enn dem veisøker har. En lyttende veilederrolle kan ha som utgangspunkt at veileder bestemmer at seg for å innta en slik veilederrolle på tross av at veisøker ber ettertrykkelig om råd. I et slikt tilfelle vil man kunne argumentere for at veileder er den bestemmende og dirigerende på tross av at hun inntar en lyttende rolle. Tilsvarende vil plasseringen av alle rollene i modellen kunne problematiseres.

Videre er det klart at andre utvalg av kilder enn dem som er vektlagt her kunne gitt andre bilder av hvilke forventninger som rettes mot veilederutdanningen og utøvelse av veilederrollen. For eksempel vil det være interessant å unders $\emptyset$ ke interaksjonene som skjer i veilederutdanningen med fokus på hvordan 
foredragsholdere eller emneansvarlige formidler forventninger til veilederes rolleut $\varnothing v e l s e . ~ K o n k l u s j o n e n$ må bli at det tankeredskapet som er presentert i denne artikkelen er tjenlig for å belyse potensielt ulike måter å ut øve veilederrollen på og hvordan forventninger til veilederrollen uttrykkes i ulike kilder. Det er altså duket for mer forskning på hvordan forventninger til veilederrollen uttrykkes og kan påvirke veiledning.

\section{Referanser}

Achinstein, B. (2006). New teacher and mentor political literacy: Reading, navigating and transforming induction contexts. Teachers and Teaching, 12(2), 123-138.

Aspfors, J. \& Fransson, G. (2015). Research on mentor education for mentors of newly qualified teachers: A qualitative meta-synthesis. Teaching and Teacher Education, 48, 75-86.

Bjerkholt, E. (2013). Åpning av lukkede rom: en kvalitativ studie av innholdet og dialogene $i$ veiledningssamtaler mellom nyutdannede lærere og lokale veiledere (Doktoravhandling). Universitetet i Oslo.

Bjørndal, C. R. P. (2008). Bak veiledningens dør: symmetri og asymmetri i veiledningssamtaler (Doktoravhandling). Universitetet i Troms $\varnothing$.

B $\emptyset$, I. \& Helle, L. (2008). Pedagogisk ordbok: praktisk oppslagsverk i pedagogikk, psykologi og sosiologi (2. utg.). Oslo: Universitetsforlaget.

Caspersen, J. \& Raaen, F. D. (2014). Novice teachers and how they cope. Teachers and Teaching, 20(2), 189-211.

Clutterbuck, D. (2004). Everyone needs a mentor: Fostering talent in your organisation (4. utg.). London: Chartered Institute of Personnel and Development.

Fitzgerald, T. (2012). Documents and documentary analysis. I A. R. J. Briggs, M. Morrison \& M. Coleman (Red.), Research methods in educational leadership and management (s. 296-308). London: SAGE Publications.

Franke, A. \& Dahlgren, L. O. (1996). Conceptions of mentoring: An empirical study of conceptions of mentoring during the school-based teacher education. Teaching and Teacher Education, 12(6), 627641.

Føinum, M. (2018). Veiledningssamtaler med nyutdannede lærere: Hvilke tema prioriteres? Acta Didactica Norge 12(3), 1-24.

GNIST. (2010). Veilederutdanning av mentorer for nyutdannede lærere - forslag til rammer for utdanningen. Hentet fra https://www.regjeringen.no/globalassets/upload/kd/vedlegg/uh/gnist/veilederutdanning arbeidsg rupperapport.pdf

Handal, G. \& Lauvås, P. (1983). På egne vilkår: en strategi for veiledning med lærere. Oslo: Cappelen Akademisk Forlag.

Handal, G. \& Lauvås, P. (1999). På egne vilkår: en strategi for veiledning med lærere (2. utg.). Oslo: Cappelen Akademisk Forlag.

Helleve, I. \& Langørgen, K. (2010). Veilederutdanning. I K. Smith \& M. Ulvik (Red.), Veiledning av nye lærere. Nasjonale og internasjonale perspektiver (s. 176-190). Oslo: Universitetsforlaget.

Hobson, A. J., Ashby, P., Malderez, A. \& Tomlinson, P. D. (2009). Mentoring beginning teachers: What we know and what we don't. Teaching and Teacher Education, 25(1), 207-216.

Hobson, A. J. \& Malderez, A. (2013). Judgementoring and other threats to realizing the potential of school-based mentoring in teacher education. International Journal of Mentoring and Coaching in Education, 2(2), 89-108. 
Hvordan påvirker veilederutdanningene utøvelse av veilederrollen? En analyse av forventninger uttrykt $i$ styringsdokumenter, forskning og faglitteratur

Kunnskapsdepartementet. (2009). Læreren: rollen og utdanningen (Meld. St. 11 (2008-2009)). Hentet fra: https://www.regjeringen.no/no/dokumenter/stmeld-nr-11-2008-2009Lid544920/?q=stortingsmelding\%2011

Kunnskapsdepartementet. (2013). Nasjonale retningslinjer for lektorutdanningen 8-13. Hentet fra https://uit.no/Content/306735/Nasjonaleretningslinjer\%20LU\%208-13.pdf

Kvale, S. (2007). Livslang læring og veiledning i et postmoderne forbrukersamfunn. I T. Kroksmark \& K. Åberg (Red.), Veiledning i pedagogisk arbeid (s. 56-67). Bergen: Fagbokforlaget.

Lakatos, I. (1974). Falsification and the Methodology of Scientific Research Programmes. I I. Lakatos \& A. Musgrave (Red.), Criticism and the Growth of Knowledge (s. 91-196). New York: Cambridge University Press.

Lauvås, P. \& Handal, G. (1990). Veiledning og praktisk yrkesteori. Oslo: Cappelens forlag.

Lejonberg, E. (2016). Hva kan bidra til god veiledning?: En problematisering basert på veilederes og veisøkeres perspektiver på veiledning av begynnende lærere (Doktoravhandling). Universitetet $\mathrm{i}$ Oslo.

Lejonberg, E. (2018). Lektorstudenter i praksis: mestringsforventninger og vurderinger av veiledning. Uniped, 41(03), 304-318. DOI: 10.18261/issn.1893-8981-2018-03-10

Lejonberg, E., Dahl, A. K. \& Brovoll, S. P. (akseptert). Nye forventninger til veilederrollen: veileder som leder av utviklingsprosjekter i skolen. I K. Helstad \& S. Mausethagen (Red.), Nye lederroller i skolen. Oslo: Universitetsforlaget.

Lejonberg, E., Elstad, E. \& Christophersen, K.-A. (2015). Mentor education: challenging mentors' beliefs about mentoring. International Journal of Mentoring and Coaching in Education, 4(2), 142-158. https://doi.org/10.1108/IJMCE-10-2014-0034

Lejonberg, E. \& Tiplic, D. (2016). Clear Mentoring: Contributing to mentees' professional self-confidence and intention to stay in their job. Mentoring \& Tutoring: Partnership in Learning, 24(4), 290-305.

Lindgren, U. (2005). Experiences of beginning teachers in a school-based mentoring program in Sweden. Educational Studies, 31(3), 251-263.

Mathisen, P. (2015). Mentor: mentoring i teori og praksis (2. utg.). Bergen: Fagbokforlaget.

Mathisen, P. \& Bjørndalen, C. (2007). Forord. I T. Kroksmark \& K. Åberg (Red.), Veiledning i pedagogisk arbeid (s. 5-13). Bergen: Fagbokforlaget.

NRLU. (2017). Nasjonale retningslinjer for praktisk pedagogisk utdanning. Hentet fra https://www.uhr.no/ f/p1/i13d351d8-d4a8-4c93-ac64-f0d2fbbdc6c6/godkjente-retningslinjerppu.pdf

Ottesen, E. (2006). Talk in practice: analysing student teachers' and mentors' discourse in internship (Doktoravhandling). Universitetet i Oslo.

Rambøll. (2014). Veiledningsordning for nytilsatte nyutdannede lærere og barnahagelærere. Resultater fra kartleggingen 2014. Hentet fra http://static.websys.no/files/sites/veiledning-

nyutdannede.hit.no/contentfiles/201404/2014 barnehager veiledningsordningen kartlegging.pdf

Rambøll. (2015). Evaluering av veiledningsordningen for nyutdannede pedagoger i barnehage og skole. Hentet fra http://www.udir.no/globalassets/filer/tall-og-forskning/forskningsrapporter/nydelrapport-evaluering-av-veiledningsordningen-for-nyutdannede-pedagoger-i-barnehage-og-skolevedlegg-inkl.pdf

RambøIl. (2016). Veiledning av nyutdannede barnehagelærere og lærere: en evaluering av veiledningsordningen og veilederutdanningen. Hentet fra https://www.udir.no/globalassets/filer/tall-og-forskning/rapporter/2016/evaluering-avveiledningsordningen-sluttrapport.pdf

Robson, C. (2002). Real World Research: A resource for social scientists and practitioner-researchers (2. utg.). Oxford, UK: Blackwell Publishing. 
Rolle. (u.å.). I Bokmålsordboka. Hentet 15. mai 2019 fra https://ordbok.uib.no/perl/ordbok.cgi?OPP=rolle\&ant bokmaal=5\&ant nynorsk=5\&bokmaal=+\&or dbok=begge

Silverman, D. (2011). Interpreting qualitative data: a guide to the principles of qualitative research (4. utg.). Los Angeles: SAGE publications.

Skagen, K. (1998). A mind free from distraction: a micro-sociological study of supervision conferences in teacher training (Doktoravhandling). Universitetet i Troms $\varnothing$.

Skagen, K. (2007). Et tema av "ytterste viktighet" - Om veiledning i det senmoderne. I T. Kroksmark \& K. Åberg (Red.), Veiledning i pedagogisk arbeid (s. 34-55). Bergen: Fagbokforlaget.

Skagen, K. (2013). I veiledningens landskap: innføring i veiledning og rådgivning. Oslo: Cappelen Damm Akademisk.

Skagen, K. (2016). Kunnskapstyper og hegemonisk veiledningsstrategi i norsk veiledningsdiskurs. I A.-L. Østern \& G. Engvik (Red.), Veiledningspraksiser i bevegelse: Skole, utdanning og kulturliv (s. 59-80). Bergen: Fagbokforlaget.

Smith, K. (2016). Mentorer - skolebaserte lærerutdannere: ansvar og krav. I A.-L. Østern \& G. Engvik (Red.), Veiledningspraksiser i bevegelse: Skole, utdanning og kulturliv (s. 197-209). Bergen: Fagbokforlaget.

Smith, K. (2018). Mentorrollen - norske og internasjonale stemmer. I K. Smith \& M. Ulvik (Red.), Veiledning av nye lærere. Nasjonale og internasjonale perspektiver (2. utg.) (s. 23-40). Oslo: Universitetsforlaget.

Smith, K., Ulvik, M. \& Helleve, I. (2013). Førstereisen. Lærdom hentet fra nye læreres fortellinger. Oslo: Gyldendal akademisk.

Stålsett, U. E. (2006). Veiledning i en lærende organisasjon. Oslo: Universitetsforlaget.

Sundli, L. (2001). Veiledning i lærerutdanningens praksis: mellom refleksjon og kontroll (Doktoravhandling). Høgskolen i Oslo.

Sundli, L. (2002). Veiledning i virkeligheten: praksisveiledning med lærerstudenter. Oslo: Gyldendal akademisk.

Ulvik, M. \& Sunde, E. (2013). The impact of mentor education: does mentor education matter? Professional Development in Education, 39(5), 754-770.

Utdannings- og forskningsdepartementet. (2002). Kvalitetsreformen: om ny lærerutdanning: mangfoldig - krevende - relevant (St.meld. nr. 16 (2001-2002)). Hentet fra https://www.regieringen.no/contentassets/ae31935c94ff4c169cc1c378e4a1be1d/no/pdfa/stm200 $\underline{120020016000 d d d p d f a . p d f}$

Utdanningsdirektoratet. (2018). Veiledning av nyutdannede. Hentet fra https://www.udir.no/kvalitetog-kompetanse/veiledning-av-nyutdannede/

Østern, A.-L. \& Engvik, G. (2016). Perspektiver på veiledningspraksiser i bevegelse. I A.-L. Østern \& G. Engvik (Red.), Veiledningspraksiser i bevegelse: Skole, utdanning og kulturliv (s. 11-18). Bergen: Fagbokforlaget. 